\title{
Integrity at the Croatian Medical Journal
}

Published at www.cmaj.ca on May I2, 2008. Revised on May I5, 2008.

$\mathrm{E}$ ditorial independence has surfaced as an issue at the Croatian Medical Journal in the wake of a confrontation between the journal and the most powerful of its 4 owners, the Zagreb University School of Medicine. Most recently, the school has proposed an extensive revision to the journal's governance structure that would rob the journal of its independence, ${ }^{1}$ in contravention of almost every aspect of the International Committee of Medical Journal Editors recognized definition of editorial independence. ${ }^{2}$

This is an extreme incident, but, sadly, not an isolated one in biomedical publishing. Within the last decade $J A M A,{ }^{3}$ the New England Journal of Medicine ${ }^{4}$ and $C M A{ }^{5}$ have all had confrontations with their publishers over editorial independence. But the complexity in each of those cases pales in comparison with the long and convoluted narrative of events in Croatia.

The path leading to that regretful situation is perilously long and twisted. We lack independent knowledge of all the events described in 2 recent Croatian Medical Journal editorials; ${ }^{6,7}$ however, several facts have emerged. The current problems can be traced back $\mathrm{I} 6$ years, to when Iain Chalmers of the James Lind Library in Oxford, England, discovered an instance of extensive plagiarism in a paper coauthored by Zagreb University Professor Assim Kurjak. Chalmers reported the plagiarism to the Zagreb University School of Medicine, which requested Chalmers" "tactful handling of this case." Chalmers acquiesced but, in 2002, discovered that Kurjak had also plagiarized material from a doctoral thesis and published it as a book chapter.

Due to Chalmers' revelations, the Croatian Medical Journal was obliged by international standards of scientific conduct and publishing to scrutinize all the articles authored by Kurjak that it had published. The Croatian Medical Journal asked the World Association of Medical Editors and the Committee on Publication Ethics for an independent investigation. These organizations identified 5 other potential transgressions. The Croatian Medical Journal subsequently retracted 2 articles, which Kurjak had previously published elsewhere.

The Zagreb School of Medicine confirmed both the plagiarism and duplicate publication and in November 2007, its Court of Honour acknowledged that Kurjak had behaved unethically. However, it judged that, because Kurjak had retired, the apologies submitted to those concerned were adequate. It dismissed the case, thereby implicitly sanctioning Kurjak's behaviour. Chalmers wrote: "This is a sad day for Croatian scientists who wish to promote honesty and to outlaw misconduct and cronyism within academia." 9

Some might argue that a journal's responsibility ends with the reporting of cases of plagiarism and the retraction of the articles in question..$^{10}$ However, as agents of change, with the overarching aim of improving journals and, thus, the evidence by which medicine is practised, journals have an additional responsibility to follow through on unsatisfactorily resolved cases. If medical journals do not take a stand on these issues, we risk having our integrity compromised. Indeed, a recent article in Nature opines that journals need to take allegations of plagiarism more seriously. ${ }^{11}$

Owing to the lack of a prompt and proper handling of this case, Professor Matko Marusic, I of 2 editors-in-chief of the Croatian Medical Journal, went to the lay media. ${ }^{12}$ In an Oct. 28, 2007, article, Croatia's leading Catholic newspaper quoted him talking about the "moral and intellectual crisis of the Croatian academic community."

Marusic is a whistle-blower: he saw what he construed to be a miscarriage of justice and, at considerable risk to his livelihood, went to the media. The Zagreb School of Medicine has the necessary bylaws to prevent him from communicating publicly about a case in progress, and it has every right to launch an investigation into his actions. But the school took the matter a step further.

The school has turned against the Croatian Medical Journal itself, calling into question the journal's track record and Matko Marusic's performance. In March 2008, it requested, as a preliminary step in disciplinary action, a psychiatric opinion of Marusic. In early May 2008, Marusic apologized to the school for speaking out, in contravention of its bylaws and, on May I4, 2008, the Zageb School of Medicine officially reprimanded him and closed the case. Nevertheless, the fact remains that the school did not follow the due process as set out in the journal's governance agreement. ${ }^{13}$ That agreement states that the journal's Editorial Board is responsible for electing and dismissing the editor-in-chief; any decisions have to be confirmed by the journal's Joint Management Board, whose members are chosen by its owners, the 4 schools of medicine of Croatia. Both the Editorial Board and the Joint Management Board must agree on these human resource decisions. The Mediterranean Editors and Translators have called this governance structure the "gold standard for small journals."14

The controversy now centres on proposed changes to the journal's governance structure. On Mar. 25, 2008, the Zagreb University School of Medicine's dean, Nada Cikes, formally proposed an extensive revision of the journal's governance structure that would rob the journal of its independence. In fact, the word "independent" has been omitted from clause III of the proposed revision. ${ }^{15}$ The proposal also calls for the deans of the other 3 medical schools to appoint or dismiss members of the journal's Editorial Board, effectively making the journal a house organ of the universities. Currently, the editors make these appointments. Four of the 8 members of the Croatian Medical Jour- 
nal's Joint Management Board rejected the proposed changes to the governance agreement and advised their respective deans not to accept it. ${ }^{1}$ The deans have now referred the issue to the councils of their schools.

The Croatian Medical Journal called in Dr. John Hoey, $C M A$ )s former editor-in-chief, who was dismissed in February 2006, to offer an expert opinion on the proposed changes. ${ }^{16}$ Hoey, who terms the proposal a "castration of the editorial independence of the Croatian Medical Journal," writes that if the changes are accepted by all 4 owners, the journal "will no longer be the $C M J$ and will no longer meet internationally accepted standards for independence in research and publication. ${ }^{16}$ In other words, the journal will cease to be.

In an interview with Science, Cikes said, "The whole thing is immobilizing parts of the institution." She then added, "I am happy and proud that we have such a good journal."17

Croatia should be proud of this world-class journal. Founded just 17 years ago, the journal has a solid reputation in the international community and is exemplary in its efforts to foster authorship ${ }^{18}$ and improve the quality of medical research, practice and education in Croatia. It has been a staunch participant in the international arena for years; the journal's co-editor Ana Marusic, for example, is the current president of the Council of Science Editors. With this case, and the ensuing international furor, the country risks marginalizing its own medical and research community and is sending the wrong message to the European Union, which it is trying to join. Everyone involved in this case must rise above the maelstrom and focus on the principle of editorial independence. The World Association of Medical Editors "strongly supports the Marusics' efforts to address ethical breaches by authors in the pages of the journal. ${ }^{119} \mathrm{We}$ at $C M A J$ concur. The Croatian Medical Journal editors are to be congratulated for their thorough handling of these cases of plagiarism and duplicate publishing and for their stalwart stand for editorial independence.

As we at $C M A J$ well know, relationships between editors and publishers are never simple. Both lose whenever a publisher tampers with editorial independence: the publisher's reputation is tarnished, and the journal's integrity is compromised. Following the events of February 2006 at $C M A J$, the principal authors of this editorial made the considered decision to remain with the journal to see it through an independent review process. That review ${ }^{20}$ resulted in a stronger governance structure that assures editorial independence.

Based on this experience, we urge the Zagreb University School of Medicine to seek an independent assessment by an international panel or impartial individual to review the governance structure of the Croatian Medical Journal and mediate a solution that ensures editorial autonomy.
In the end, this is not only about the Croatian Medical Journal; it is about the integrity of all biomedical journals. Without editorial independence the integrity of journals and, de facto, the knowledge of medicine, will wither.

\section{Barbara Sibbald BJ \\ Deputy Editor, News and Humanities \\ CMAJ}

Ken Flegel MDCM MSc

Senior Associate Editor

CMAJ

With the Editorial-Writing Team (Paul C. Hébert MD MHSc, Rajendra Kale MD, Matthew B. Stanbrook MD PhD and Noni MacDonald MD MSc)

Competing interests: See www.cmaj.ca/misc/edboard.shtml.

\section{REFERENCES}

I. Marusic M, Marusic A. Discussing the future of the journal. Croat Med 2008;49:158-60.

2. International Committee of Medical Journal Editors (ICMJE). Uniform requirements for manuscript submission to biomedical journals. Available: www.icmje .org (accessed 2008 May 9).

3. Hoey J, Caplan C, Elmslie T, et al. Science, sex and semantics: the firing of George Lundberg. CMAJ I999;160:507-8.

4. Mitka M. NEJM editor Jerome P. Kassirer, MD, loses post over "administrative issues." JAMA I999;282:622-3.

5. Shuchman M, Redelmeier DA. Politics and independence - the collapse of the Canadian Medical Association Journal. N Engl J Med 2006;354:1337-9.

6. Marusic M, Marusic A. Threats to the integrity of the Croatian Medical Journal [editorial]. Croat Med J 2007;48:779-85.

7. Marusic M, Marusic A. Threats to the integrity of the Croatian Medical Journal: an update [editorial]. Croat Med J 2008;49:8-II.

8. Chalmers I. Role of systematic reviews in detecting plagiarism: case of Asim Kurjak. BMJ 2006;333:594-6.

9. Kmietowicz Z. University drops case against Croatian academic accused of plagiarism. BMJ 2007;335:I0I4

Io. Seitz HJ. Ongoing strong development of science and culture in Croatia is impressive. Croat Med J 2008;49:105.

II. Jefferson T, Shashok K. Journals: How to decide what's worth publishing. Nature 2003;42I:209-IO.

I2. Same people keep appearing at governing positions [in Croatian]. Glas Koncila 2007 Oct 28. Available: www.cmj.hr/2008/49/I/Interview_Glas_Koncila.htm (accessed 2008 May 9).

I3. Marusic M, Bosnjak D, Rulic-Hren S, et al. Legal regulation of the Croatian Medical Journal: model for small academic journals. Croat Med J 2003;44:663-73.

I4. Council of Mediterranean Editors and Translators, Marc C, Kerans ME. Thanking the Croatian Medical Journal for providing a model of high editorial standards. Croat Med J 2008;49:103.

I5. Agreement on the governance of the Croatian Medical Journal - proposal for change by the Zagreb University School of Medicine. Available: www.cmj.hr/2008 /49/2/web_extra_Marusic_forum.htm (accessed 2008 May 9).

I6. Hoey J. Crisis at the Croatian Medical Journal: considering a proposal for its destruction. Croat Med J 2008;49:I6I-3.

I7. Vogel G. Croatian editors fight with medical school over journal's fate. Science 2008;320:304-5.

I8. Ilakovac V, Fister K, Marusic M, et al. Reliability of disclosure forms of authors' contributions. CMAJ 2007;176:4I-6

I9. Shane P, et al. World Association of Medial Editors: support for the Croatian Medical Journal's Editorial Independence. Croat Med J 2008;49:100.

20. CMAJ Governance Review Panel. Final report. Ottawa (ON): The Panel; 2006. Available: www.cmaj.ca/pdfs/GovernanceReviewPanel.pdf and www.cmaj.ca/pdfs lappendices.pdf (accessed 2008 May 9). 